UDK: 374.7:005]:373.3(497.6)

DOI: $10.53617 /$ issn2744-2047.2021.21.1.93

Stručni rad/Professional paper

Primljeno/Received: o I. 09. $202 \mathrm{I}$.

Prihvaćeno/Accepted: I 5. IO. 202I.

Azra Jasika ${ }^{1}$

\title{
Andragoški praktikum za obrazovni menadžment - VIARO model u programu rukovodilaca
}

Sažetak: U ovom radu argumentira se potreba uvođenja cjelovitog programa obuke namijenjenog rukovodiocima škola kao poslovnih organizacija, te se izvode preporuke za njegovu primjenu. Predlaže se da dio tog programa čini obuka o sastancima - od pripreme i vođenja sastanaka, do donošenja odluka i njihove provedbe. Centralna tema bila bi osposobljavanje svih zaposlenih u jednoj organizaciji za aktivnu participaciju u radu na sastancima. Preporuke sadržane u programu nastale su na temelju rezultata provedenog istraživanja sa direktorima škola, analize dokumentacije i samorefleksije autorice na vlastiti rukovoditeljski rad. Model VIARO kao sredstvo i alat za unapređenje kompetencija svih zaposlenih u školi u ulozi učesnika sastanaka počiva na pet elemenata: vrijeme, iskustva, analize, razlozi i obuke. U radu je opisana njegova uloga, ciljevi i značaj iz perspektive ishoda učenja i obrazovanja odraslih.

Ključne riječi: obrazovni menadžment, rukovođenje, sastanci, program obuke, praktikum, model VIARO.

\footnotetext{
${ }^{1}$ Mr. Azra Jasika, JU OŠ „Silvije Strahimir Kranjčević“ Sarajevo; e-mail: jasika.azra@gmail.com
} 


\section{Uvod}

Svjedoci smo brzih i temeljnih promjena u obrazovanju djece, mladih i odraslih, posebno u vrijeme ozbiljnih kriza, poput posljednje izazvane koronavirusom. Efikasne mjere traže se u svim sferama života i rada: u nauci, tehnici, ekonomiji, tehnologiji, menadžmentu. Otkrili smo, ponovo, da ključni resurs u svakoj od tih sfera života predstavljaju ljudi - znalci i profesionalci koji aktivno koriste znanje, informacije, vrijeme i materijalna sredstva radi dobrobiti svih. Kad su funkcionalno organizirani i iskorišteni, dat će željeni rezultat. Paket zvani formalno obrazovanje u znanostima o odgoju i obrazovanju nije u stanju sve to objediniti i obuhvatiti, te je potrebna nadogradnja kroz procese usavršavanja i daljnjeg obrazovanja. Oba koncepta učenja i obrazovanja, formalni i neformalni, uspješniji su kad se oslone na iskustvo učesnika, odnosno integrišu se i funkcionišu u simbiozi koja donosi uspjeh u učenju i obrazovanju odrasle osobe. Sa čime ili s kim će uporediti lična znanja i iskustva rukovodilac škole kad je imenovan na tu poziciju i dođe u situaciju da organizira i održi jedan sastanak u školi? Pred njim je izazov za koji nema formalno obrazovanje, a možda nema ni mogućnost da transferira ranije lično iskustvo. Odabir pristupa je različit. Jedni će tragati za izvorima i literaturom te doći do niza teorijski datih inputa kako bi trebalo pristupiti tom problemu. Drugi će se osloniti na iskustvo bivšeg kolege ili rukovodioca, a treći će učiti upravljati „upravljajući“. Svi imaju isti cilj: postići što bolje rezultate u radu i povećati efikasnost učesnika odgojno-obrazovnog procesa, kao i rada na sastancima.

Kako bi se izbjeglo učenje putem pokušaja i pogrešaka, u odgovoru na potrebe rukovodilaca predlažemo uvođenje strukturiranog Programa obuke o sastancima. Ideja je nastala kao rezultat dvogodišnjeg istraživanja i proučavanja literature o sastancima. Kroz Praktikum ${ }^{2}$ koji bi bio osnova Programa obuke, ostvaruje se više ciljeva: unapređenje pripreme i rada na sastancima, osposobljavanje rukovodilaca škola za što uspješnije vođenje sastanaka $i$ upravljanje pomoću sastanaka. Ovaj obavezujući program, temeljen na modelu VIARO, mogao bi zamijeniti postojeće modele obuke, zasnovane na principu dobrovoljnosti i

\footnotetext{
2 Praktikum, kao osnova programa obuke za rukovodioce, potaknut je idejom iz literature o sastancima (v. Grković 2002; 2004), a razvijan je tokom istraživanja provedenog 2012. i 2013. godine. Prolazeći, korak po korak, sve faze sastanaka, na bazi uvida u rezultate i iskazane potrebe rukovodilaca škola iz uzorka, sistematično smo unosili one elemente koji bi mogli unaprijediti rad na sastancima i tako strukturirali Praktikum.
} 
ličnom izboru tema i/ili programa. Andragoški stručnjaci iz područja upravljanja sastancima realizirali bi obuku za rukovodioce koja bi bila obavezujuća za sve pojedince koji su tek preuzeli rukovodeću poziciju ili kandidate koji imaju aspiracije za tim. Umjesto potvrda o prisustvu ili certifikata o učešću, nakon obuke bi se uradio proces licenciranja onih koji su uspješno završili program. U biti, kreće se u proces promjene stavova ili uloga rukovodilaca o sastancima, kako bi učenje i obrazovanje preuzeli kao „pogonsku energiju“ (Alibabić 2010: 105) u transformacijskim procesima promjene u svojoj organizaciji. Brojna određenja organizacije koja uči uglavnom polaze od stava da je učenje „utkano“ u život takve organizacije. Namjera ovog rada je potaknuti rukovodioce da budu pokretači razvoja organizacije vođeni motom da ako želiš promjenu - budi dio promjene. Prvi korak na putu promjene jeste otvorenost za učenje temeljeno na prakticiranju naučenih obrazaca i redovnoj analizi učinjenog, ali i na samorefleksiji. ${ }^{3}$

\section{Obrazovni menadžment kao polazište promjene}

Menadžment u obrazovanju, prema Staničiću (2008) razumijeva se kao rukovođenje i vođenje u obrazovanju, na nivou teorije i u praksi. To uključuje „upravljanje cjelokupnom djelatnošću odgoja i obrazovanja, rukovođenje prosvjetnim ustanovama, vođenje odgojno-obrazovnog i drugog osoblja u obrazovnim ustanovama, unutarnji razvoj te organizaciju radnog procesa u školi.“ (v. Staničić 2008: 1). Isti autor ukazuje na to da je menadžment u obrazovanju istovremeno naziv za stručno područje, znanstvenu disciplinu, profesiju i funkciju. U širem smislu, menadžment u obrazovanju odnosi se na upravljanje i rukovođenje u cjelokupnoj obrazovnoj djelatnosti i tada je riječ o obrazovnom menadžmentu. U užem smislu, znači rukovođenje i vođenje u školi, što je posao (ruko)voditelja odgojno-obrazovnih ustanova i tada je riječ o školskom menadžmentu (Ibid). Današnje društvo, pa i škola kao njegov nedjeljiv segment, postali su već odavno mjestom izazova za pojedinca koji želi da uči. Cjelokupni proces se realizira kroz osnovne menadžerske funkcije: planiranje, organiziranje, upravljanje ljudskim resursima, vođenje i kontrolu.

\footnotetext{
${ }^{3}$ Autorica ovog rada je, kao višegodišnja rukovoditeljica u školi i aktivna učesnica reformskih procesa u obrazovnom sektoru, temeljito pristupala pripremi za sastanke na koje je pozvana ili ih je sama organizirala, potom je aktivno učestvovala u njihovom radu i nakon toga vodila diskusije sa drugima o načinu učešća i doprinosu sastanku i/ili radila samorefleksiju na sastanku sa samom sobom (Schulz von Thun 2001).
} 
Ako na upravljanje organizacijom gledamo kao na niz aktivnosti rukovodioca koji, uz pomoć ostalih zaposlenika, nastoji ostvariti misiju i ciljeve organizacije - unaprijediti kvalitet rada škole i postignuća učenika - onda je taj proces nezamisliv bez sastanaka. Naime, kad se dvoje i više ljudi sastane da bi razmijenili informacije, prodiskutovali o idejama i usaglasili stavove radi zajedničkih poslovnih interesa, onda oni učestvuju u slučajnim ili organiziranim sastancima. Rukovodilac organizacije ili voditelj dijela radnih procesa, u nizu aktivnosti koje poduzima u školi, sastanke koristi kao mehanizam za uključenje ljudi i pokretanje svih raspoloživih resursa, zarad veće efikasnosti u radu i razvoju organizacije. Samo saznanje da sastanci predstavljaju takav organizacioni model u okviru kojeg se istovremeno većem broju učesnika izlaže, obrazlaže i pokazuje ono što je nužno za razumijevanje teme ili problema koji se aktuelizira, podupire kod učesnika svijest o uključenosti u procese upravljanja. Ovaj model rada poželjno je dalje razvijati prema konceptu PAEI koji Adižes (2004) zagovara kao ključ uspjeha, a zasniva se „na komplementarnom timu, koji usvaja i sprovodi princip uzajamnog poštovanja, a to znači da svako prihvata stil onog drugog kao legitiman “ (Ibidem: 263). Rukovodioci time prenose poruku o podijeljenoj odgovornosti i na putu ostvarenja menadžerskih funkcija imaju mogućnost efikasnije upravljati vremenom, ljudskim i materijalnim resursima. Cilj je razviti kompetencije za uspješno obavljanje pojedinačnog posla, grupe poslova ili funkcije kod svih zaposlenih u školi. Dobro strukturirani elementi nadzora (vanjske kontrole) i vođenja pomoću mekih menadžerskih funkcija omogućavaju rukovodiocima škola da sastanke koriste kao priliku za učenje i razvoj - pojedinačno i timski. To je posebno bitno kad se na njih gleda u širem kontekstu poimanja menadžmenta u obrazovanju, kao „(...) krajnje složenog i integriranog znanja različitih znanstvenih disciplina o procesima upravljanja poslom i ljudima u obrazovanju i školi. Međutim, menadžment nije neka suvremena znanstvena disciplina nego umijeće utemeljeno na odgovornosti i na različitim, ali međusobno povezanim znanjima“ (Slatina 2012: 23).

Škola, kao institucionalno formirana profesionalna organizacija, čini jedan zaseban socijalni sistem, temeljem dogovora svojih članova i osnivača. U njoj rade pojedinci koji svoja specifična stručna znanja i vještine, stečena obrazovanjem, stavljaju u funkciju razvoja drugih. Uporedo s tim, svako od njih nastoji zadovoljiti svoje interese i potrebu za profesionalnom uspješnošću i afirmacijom. Ovim 
činjenicama određena je dvojna uloga učesnika u procesu rada - prvo, neposredni su izvršioci definiranih aktivnosti u poučavanju djece i mladih i, drugo, nastoje kontinuirano raditi na sebi. U odnosu na načine, strategije i puteve ličnog razvoja, naglašava se značaj kontinuiranog profesionalnog obrazovanja. „Kontinuirano obrazovanje se određuje kao obrazovanje koje se dešava na univerzitetu ili van njega, formalno ili neformalno, ali svakako posle završenih studija (strukovnih ili akademskih) koje su 'ulaznica’ u profesiju“ (Alibabić 2011:85). Kontinuirano obrazovanje, također, ima svrhu potpunijeg osposobljavanja za efikasno obavljanje profesionalnih uloga (Savičević 2000 prema Ibidem).

Organizacionu strukturu škole čini određeni broj nezavisnih radnih grupa: od organa upravljanja, preko članova stručnih organa, do osoblja za podršku osnovnoj djelatnosti. Iz perspektive nekih autora (Avdagić 2016: 14), upravljanje u školama kao javnim obrazovnim ustanovama je uglavnom „kruto nadzirana organizacija unutar rigidnog sistema, gdje nema puno prostora za samostalno odlučivanje i inovativno vođenje“. Kao otežavajuća okolnost u tom formalnom sistemu obrazovanja navodi se stav da isti „(...) ne uvažava načela tržišta rada i konkurentnost kvaliteta, pa se u takav kontekst menadžmenta ne može uklopiti obrazovanje odraslih“. Ovo kritičko propitivanje zanemaruje neke od važnih odrednica strategijskog menadžmenta (Alibabić 2010: 105) koje se trenutno prepoznaju u organizacijama poput javnih škola:

- menadžment timovi i sami rukovodioci javnih škola, na svim nivoima organizovanja, i sami su usmjereni osvajanju novih područja znanja i vještina da bi unaprijedili rukovođenje razredom ili školom - tj. poistovjećuju se s menadžmentom promjena kroz TQM, UPC, UPS i druge modele - zauzimajući proaktivan stav u odnosu na izazove vanjskog okruženja i crpe rješenja iz koncepta strategijskih i organizacijskih promjena, zasnovanih na obrazovanju i učenju;

- kandidati na konkursima prave sebi liste prioriteta kod zapošljavanja u školama (kad su u prilici birati poslovno okruženje) - što u praksi znači da strategijski menadžment nalazi i dobija dodatnu podršku promjenama zbog radne klime i kulture organizacije;

- mjerila uspješnosti uvode se i u javnim ustanovama, pa se neke škole s pravom mogu smatrati „rezilijentnim školama“, „inkluzivnim školama“, „školama bez nasilja“ i slično, i za sve njih vrijedi načelo 
ponude i potražnje (načelo konkurentnosti kvaliteta), bez javnih poziva ili oglašavanja jer su dovoljne preporuke dosadašnjih korisnika usluga;

- vrijednosni okvir u tim javnim ustanovama uspostavljaju zaposleni profesionalci, koji mijenjaju praksu jer to sami žele ili ih na to primorava dolazak novih generacija učenika koje sa sobom donose drugačiju percepciju ličnih potreba i interesa, pristupe učenju i stilove komunikacije - što mijenja kulturu organizacije i koncepcijski odgovara jednom od postulata strategijskog menadžmenta u smislu podrške promjenama.

Osnovnoškolske ustanove jesu i mogu biti provajderi (pružaoci usluga) u oblasti učenja i obrazovanja odraslih, ako ih gledamo u odnosu na funkciju (zadatak) i rezultate (ishode). Brojne pružaoce usluga u sferi učenja i obrazovanja odraslih prema Körberu (v. Avdagić 2016: 30) moguće je razvrstati u sedam kategorija. Tamo gdje škole jesu ili mogu biti provajderi, dodali smo odgovarajuću naznaku:

o Stvarni provajderi obrazovanja odraslih (osnovna i jedina djelatnost je obrazovanje odraslih);

o Provajderi obrazovanja odraslih, ali i drugih aktivnosti (pored obrazovanja odraslih postoje i ostale djelatnosti);

o Provajderi koji se sporadično bave obrazovanjem odraslih - periodično se, prema godišnjem planu i programu (GPR) škole u javnim ustanovama provode obrazovni programi za roditelje;

o Provajderi koji se po potrebi bave obrazovanjem odraslih - neke javne ustanove uključene su u procese obuke i osposobljavanja odraslih koji iz različitih razloga nisu završili formalno osnovnoškolsko obrazovanje;

o Provajderi koji se interno bave obrazovanjem odraslih-obuke nastavnika u skladu sa GPR-om škole; kolege obrazuju svoje kolege na nivou stručnih organa;

o Provajderi koji nude svoje resurse i usluge za obrazovanje odraslih - neki zaposlenici škola, kao certificirani treneri, rade određene programe obuke za NVO ili vladin sektor;

o Provajderi bliski obrazovanju odraslih. 
Dakle, za četiri od sedam kategorija navedenih provajdera pronašli smo primjere i modele rada koji podupiru stav da redovne osnovne škole, kao javne ustanove, pružaju usluge učenja i obrazovanja odraslih, te da mogu biti i jesu provajderi obrazovanja odraslih. $\mathrm{Na}$ organima upravljanja i rukovodiocima je da prepoznaju svoju priliku i iskoriste prostor otvoren za njihovo aktivno učešće u domenu daljeg učenja i obrazovanja odraslih u organizaciji kojom upravljaju.

\section{Istraživački okvir}

Cilj istraživanja bio je analizirati praksu vođenja sastanaka u osnovnim školama kako bi se identificirale obrazovne potrebe rukovodilaca i svih uključenih u rad na sastancima. Istraživanje je obavljeno na uzorku od osam osnovnih škola u Kantonu Sarajevo, u kojima je tokom jedne školske godine održano ukupno 60 sjednica školskih odbora i 130 sjednica nastavničkih vijeća. Primijenjena je deskriptivna metoda, u okviru koje su provedene tehnike analize pedagoške dokumentacije, opservacije i intervjuiranja. Predmet analize bili su: dnevnici rada, lične bilješke sa sastanka i zapisnici, na osnovu kojih je bilo moguće identificirati podatke o učešću prisutnih i njihovom doprinosu radu na sastancima. Analizom pedagoške dokumentacije, konkretno zapisnika sa sjednica organa upravljanja i stručnih organa u tim školama za školsku 2010/2011. godinu, kao i kroz intervjue sa rukovodiocima i sekretarima škola, prikupljeni su, a potom kvantitativno i kvalitativno obrađeni podaci koje smo koristili za izradu zaključaka i preporuka. Jedinice analize bili su: sadržaj poziva i agendi sastanaka školskih odbora i nastavničkih vijeća, vrijeme kao faktor efikasnosti sastanaka, uključenost voditelja u izvršavanje odluka i delegiranje na saradnike, evidentiranje rokova provedbe odluka, oglašavanje sadržaja zapisnika, te spremnost rukovodilaca na usavršavanje. Ispostavilo se da je bio vrlo zahtjevan istraživački zadatak snimiti uključenost voditelja i drugih učesnika u rad na sastanku, kao i u procese donošenja odluka. Stoga smo u analizi zapisnički evidentiranih prijedloga odluka i izvršilaca pošli od sveukupnog doživljaja i razumijevanja značaja sastanka za pojedinca spram načina vođenja sastanka i metakomunikacije o sastanku. Primjenom evaluacijskog upitnika, sa 11 definiranih aktivnosti koje opisuju njihov angažman evidentiran u zapisnicima sa sjednica školskog odbora i nastavničkog vijeća, postigli smo tri cilja: 
1. Svi učesnici sastanaka su opservirani/praćeni po jedinstvenoj metodologiji.

2. Nejasnoće koje su se pojavile kod popune tih obrazaca otklonili smo kroz intervjue sa osobama koje su bile uključene u pripremu i rad na sastanku.

3. Od podataka dobivenih na ovaj način sačinili smo bazu, koja nam je omogućila daljnju statističku obradu podataka postupcima deskriptivne statistike.

Proces istraživanja i rad u cijelosti usmjereni su na učesnike sastanaka kao aktere procesa izgradnje školske klime, zato što se njihove odluke, kao i način donošenja odluka i njihove provedbe, tiču velikog broja pojedinaca unutar škole i van nje. Istovremeno, one oslikavaju nivo ličnog, ali i zajedničkog učešća osoba sa „pravom glasa” na sastancima školskog odbora i nastavničkog vijeća. $\mathrm{Na}$ sjednicama oba organa odlučivanja utvrdili smo visok nivo aktivnosti direktora/ ica škola iz uzorka, kao i članova školskih odbora i nastavničkih vijeća. Ostale rezultate do kojih smo došli predstavljamo u nastavku rada kroz opise jedinica analize.

\section{Rezultati istraživanja kao osnova za pripremu Andragoškog praktikuma}

\section{Sadržaj poziva i agendi sastanaka u školama}

Analizom agendi sastanaka u školama, izdvojili smo njihove ključne karakteristike:

- Obje školske strukture, prema pozitivnim propisima, rade na sjednicama.

- Voditelji sastanka, uglavnom, sarađuju sa ostalim učesnicima sastanka, kod izrade poziva i strukturiranja dnevnog reda, uz mogućnost predlaganja izmjena ili dopuna prije konačnog izjašnjenja o dnevnom redu.

- Odluke o dnevnom redu donesene su jednoglasno na svim sastancima upravnih i stručnih organa.

- Broj tačaka dnevnog reda na sjednicama školskih odbora i nastavničkih vijeća kretao se od jedan do 15 . 
- Više od dvije trećine sjednica obje ove strukture u školama iz uzorka imalo je od tri do šest tačaka dnevnog reda.

- Za zakazivanje sjednica upravnih organa u školama uglavnom su korišteni svi kanali komunikacije navedeni u evidencionoj listi - od poziva koji se dostavlja poštom do lične dostave po kuriru ili putem oglasne ploče. Samo jedna škola je ponekad radila zakazivanje sastanaka telefonskim putem.

- Kod zakazivanja sjednica nastavničkog vijeća, u svim školama poziv je oglašavan putem oglasne ploče. Vrlo rijetko su korišteni neki drugi kanali za obavještavanje članova stručnih organa o planiranim ili zakazanim sastancima. Izuzetak čine nastavci sastanaka za koje se odmah odredi termin i mjesto održavanja.

- Nema ponovljenih, kao ni otkazanih sjednica zbog problema sa kvorumom. Nisu evidentirana kašnjenja na sjednice upravnih i stručnih organa u školama iz uzorka.

- Zapisnički nisu konstatovani primjeri dostave prethodnih primjedbi na zapisnike ili sadržaj dnevnog reda voditelju sastanka.

- Odluke se donose većinom prisutnih učesnika sastanka, kako stoji u poslovniku o radu oba organa odlučivanja u školi - za školske odbore i za nastavničko vijeće.

Dostavljanje radnih materijala za 309 tema iz dnevnog reda školskih odbora posmatrali smo u kontekstu poštovanja odredbi poslovnika o radu i odnosa članova organa upravljanja prema odgovornosti za efikasnost u radu na sastanku. Utvrdili smo da je održana čak jedna trećina sastanaka školskog odbora za koje uz poziv nisu dostavljeni odgovarajući radni materijali. Dakle, ustaljena je praksa u školama iz uzorka da se radni materijali dijele ili predstavljaju tek na sastanku, što se odražava na pripremljenost za sastanak, rezultate rada i odlučivanje. Kod stručnih organa uočeni problem je još izraženiji. Realizacija 89,19\% tema na uzorku od 629 identificiranih tema na sjednicama nastavničkih vijeća bila je bez prethodne dostave materijala, odnosno sadržaji i teme su pročitani, predstavljeni ili izloženi na samoj sjednici. To predstavlja veliki gubitak vremena za sve učesnike tih sastanaka. 
U istraživanju su zabilježeni i primjeri dobre prakse. Prvi primjer odnosi se na strukturu poziva za sjednice školskog odbora u jednoj školi, u kojem su navedena imena uvodničara ili izvjestilaca po tačkama iz dnevnog reda. Ostali primjeri dobre prakse odnose se na postupanje tri direktorice škola koje su, za razliku od ostalih kolegica i kolega, pokazale nešto veći nivo organiziranosti u pripremi radnih materijala za sjednice nastavničkog vijeća, učinivši ih tako pravovremeno dostupnim za ostale učesnike sastanka. Ovi primjeri govore kako je moguće mijenjati praksu poštovanja odredbi poslovnika o radu u svim fazama sastanka, kako u radu organa upravljanja tako i u stručnim organima.

\section{Vrijeme kao faktor efikasnosti sastanaka}

Ustanovili smo razlike u dužini trajanja sastanaka u odnosu na vrijeme njegovog održavanja. Pokazalo se da su sastanci školskih odbora i nastavničkog vijeća zakazani u jutarnjim ili popodnevnim terminima trajali znatno kraće negoli sastanci zakazani u večernjim terminima. Prikupili smo potpune podatke o trajanju 52 sastanka školskih odbora, od ukupno 60 održanih. Utvrdili smo da prosječno trajanje sastanaka prelazi sat i 30 minuta rada. Potrošeno je preko 83,5 sati na „sastančenje” jer se neracionalno upravljalo vremenom. Stil vođenja sastanaka je jedan od niza razloga zbog kojeg su, u većini škola iz uzorka, bili vrlo dugi sastanci organa upravljanja i stručnih organa. Zašto su sastanci „kradljivci vremena”? Izdvajamo najčešće razloge: stavljanje na dnevni red tačaka i tema koje nisu iz nadležnosti organa odlučivanja, neiskorištenost različitih komunikacijskih kanala za prethodnu pripremu sastanka i bržu razmjenu informacija, veliki broj materijala koji se predstavlja na samom sastanku, kao i nedovoljna pripremljenost ili osposobljenost učesnika sastanka za učešće u raspravi. Poseban problem predstavljaju brojne ponavljajuće diskusije učesnika sastanka iz grupe "gnjavatora”, „negatora” i drugih ometača, zbog čega tok sastanka biva ugrožen, ukoliko se voditelj ne snalazi u povjerenoj mu ulozi. Ova pojava je izraženija u radu školskih odbora. Predstavljeni rezultati vode nas do zaključka da je potrebno osposobiti ili potaći voditelje sastanaka da počnu koristiti poslovničke intervencije na sjednicama, kao alat za upravljanje vremenom i kontrolu ponašanja govornika na sastanku. Stoga je važno osposobiti rukovodioce i voditelje sastanaka, kroz strukturiran program obuke o upravljanju vremenom i ljudskim resursima, kako bi sastanke učinili efikasnim. 
Za ilustraciju može poslužiti nalaz iz našeg istraživanja, gdje smo identificirali sjednicu u kojoj se pojavljivao klasični „ometač („očekivajući destruktor“) koji je svojim repetitivnim diskusijama doprinosio da sastanci organa upravljanja te škole traju najduže u ukupnom uzorku škola. $S$ druge strane, nastavničko vijeće te škole trajalo je najkraće od svih škola obuhvaćenih istraživanjem. Valja napomenuti da ista osoba participira u radu oba organa te škole. Dužina trajanja sastanaka određena je, između ostalog, i stilom njihovog vođenja, te poštovanjem pravila rada na sastancima. U ovom području se dobro strukturiranom obukom rukovodilaca mogu napraviti značajni pomaci u upravljanju vremenom i ljudskim resursima.

\section{Uključenost voditelja i delegiranje}

Nosioci posla oko pripreme sjednica školskog odbora, ali i nastavničkog vijeća, prema dobivenim rezultatima, bili su direktori/ice škola. U pripremi sjednica školskog odbora, najviše su im pomagali sekretari/ke škola, jer su u preko $50 \%$ škola bili tumači zakonskih i drugih rješenja ili izvjestioci po pojedinim tačkama iz svoje nadležnosti, sa vrlo visokim udjelom u radu i utjecajem na procese odlučivanja. Za pripremu sjednica nastavničkog vijeća, najveću podršku direktorima pružali su stručni saradnici. Njihov stepen uključenosti iznosi 53,85\%, kako stoji zapisano u zapisnicima sa sastanaka. Za ostale članove nastavničkog vijeća u zapisnicima je vrlo rijetko eksplicitno navedeno njihovo učešće u pripremnoj fazi sastanka, ali je posredno prepoznato kroz način učešća u radu na samom sastanku. Da bi prevladali teškoće i komunikacijske barijere, direktori su nastojali uraditi što kvalitetniju pripremu sastanaka na ličnom nivou i kroz podjelu zadataka na druge pojedince i timove.

Istraživanje na terenu pokazalo je da su predsjednici ili vršioci dužnosti predsjednika imali potpuno različit pristup pripremi sastanaka školskog odbora. Uočili smo, zapisnički konstatovano, 100\% učešće predsjednice jednog školskog odbora. U drugoj školi zapisnički nije evidentirano, ali nam je u intervjuu rečeno da njihova predsjednica organa upravljanja, u saradnji sa direktorom škole, priprema svaku sjednicu školskog odbora. Potom slijede oni predsjednici koji su samo djelimično uključeni u pripremu dnevnog reda sastanaka kojima su predsjedavali. Procentualno izraženo, njihovo učešće kreće se od 14,29\% do 
$73,73 \%$ održanih sastanaka. Sudeći po zapisnicima sa sastanaka, postoje i oni predsjednici koji tokom jedne školske godine nisu učestvovali u pripremi niti jednog sastanka kojem su predsjedavali. Nisu se u tome istakli ni ostali članovi školskog odbora, jer su rijetki među njima, prema evidenciji iz zapisnika, bili uključeni u te procese.

Obrađeni podaci ukazuju na sljedeće:

- direktori/ce škola su $100 \%$ involvirani u sve procese pripreme sastanaka, od izrade poziva na sastanak, do pripreme prostora i obezbjeđenja opreme potrebne za rad na sastanku.

- stil rukovođenja direktora/ice škola određuje broj saradnika i drugih članova kolektiva uključenih u pripremu sjednica, zatim načine i oblike uključenosti izvršilaca posla u toj i drugim fazama sastanka. Kroz intervjue i evaluacijski upitnik prepoznali smo da češće delegiraju direktori/ice koji su prošli obuke iz benchmarkinga i usvojili TQM kao referentnu vrijednost.

- prema broju uključenih pojedinaca, timova i komisija u pripremi sastanaka moguće je utvrditi da se nastavničko vijeće prepoznaje kao kolektivni organ rada i odlučivanja. Također, uočene su razlike među školama u pogledu uključenosti učesnika i voditelja sastanaka u pripremi sastanka i/ili njihovom ličnom učešću na sastancima tih škola.

Utvrdili smo da u istraživačkom uzorku nije bilo otkazanih sjednica zbog nedostatka kvoruma, što je jako važno za jednu profesionalnu organizaciju, iz ugla protoka informacija i davanja važnosti i značaja temama iz dnevnog reda sastanka. Na konceptu odgovornosti pojedinca za rezultat i pripadnosti grupi i organizaciji bazirani su prijedlozi odluka i zaključaka, kao i njihovih izvršilaca. Rezultati pokazuju da je u osnovi kolektivna odgovornost kao dominantni obrazac rada na sjednicama školskog odbora ili nastavničkog vijeća nametnut kao zakonski definirana obaveza, a u praksi se realizira na ličnoj osnovi i u pojedinačnom odnosu spram tema i problema koji se razmatraju na sastanku. U analizi pristupa pojedinačnim tačkama i izjašnjavanju oko konkretnih prijedloga, vidljiva je zainteresiranost učesnika sastanka za teme i rješenja koja se prvenstveno tiču njihovog ličnog i profesionalnog statusa, zatim pozicije učenika u školi i zajednici, te ugleda škole u cjelini. 


\section{Evidentiranje rokova za provodenje odluka}

Evidentiranje rokova za izvršenje određenog posla ili aktivnosti rijetko smo susretali u zapisnicima sa sjednica nastavničkog vijeća, ali su navedeni u većini odluka školskog odbora. Odluke i zaključci sadržajno definirani bez rokova ili izvršilaca proizvode teškoće nakon sastanka - u fazi njihove realizacije. U školama koje su, zapisnički korektno, uz sadržaj odluka navodile izvršioce i rokove, bilo je znatno manje nejasnoća u procesu provedbe ili problema tokom realizacije. To je jedan od modela preventivne kontrole. U nekim školama su se na dnevni red povremeno stavljala pitanja i teme koje potvrđuju tezu da nejasno definirana zaduženja, bez rokova i efikasnih mehanizama kontrole, u principu dovode do ponavljanja odluka i podsjetnika, koji štite radine izvršioce od onih manje odgovornih. Ovaj manje popularan mehanizam za uspostavu kontrole u izvršenju zadataka i dalje je bolji od sankcije. Uočeno je da ni jedan zapisnik ne sadrži podatke o tome koji je sljedeći korak ako posao ne bude korektno obavljen - razgovor voditelja sastanka sa osobom koja neredovno izvršava svoje obaveze, usmeni ili javni prijekor, opomena ili sankcija. Dakle, svi učesnici sastanaka ili značajna većina njih prihvatala je većinski donesene odluke, ali nisu uvijek i do kraja bili uključeni u njihovu provedbu. Trebali su im vanjski poticaji ili podsjetnici da bi posao doveli do kraja. Uglavnom, voditelji sastanaka u školama ponašali su se kao kampanjski redari praveći periodične intervencije radi unapređenja odnosa pojedinaca ili tima, prema dodijeljenim obavezama ili zadacima. Ovo su značajna područja za unapređenje rada na sastancima, i osnov za zagovaranje koncepta učenja i obrazovanja odraslih, prije svih rukovodilaca, radi boljeg izvršenja profesionalnih zadaća i definiranih razvojnih ciljeva organizacije. Na osnovu analize svih 190 zapisnika sa sastanaka organa upravljanja i stručnih organa ustanovili smo da oni ne sadrže sve podatke tražene uputstvom za vođenje zapisnika. Podaci o trajanju sastanaka ili učesnicima u raspravi, zatim strukturi i broju odluka i rokovima za njihovu provedbu čine dio onoga što nije precizno navedeno u zapisnicima sa sjednica, a traženo je samim uputstvom. 


\section{Oglašavanje sadržaja zapisnika sa sastanaka}

Članovi školskih uprava i sekretari škole imaju različite pristupe - oglašavanje zapisnika ili izvoda iz zapisnika - informiranja učesnika sastanka i ostalih zaposlenika o radu na sjednicama školskog odbora i nastavničkog vijeća. Pozitivan primjer nalazimo u jednoj školi u kojoj se cjeloviti zapisnici sa sastanaka tih tijela oglašavaju putem oglasne ploče. U drugoj školi oglašavaju se samo odluke školskog odbora, uz izuzetak da su sa jedne sjednice oglasili cijeli zapisnik. U intervjuima sa sekretarima tri škole iz uzorka, rečeno nam je da ne postoji zakonska obaveza da se zapisnici školskog odbora ili nastavničkog vijeća oglašavaju putem oglasne ploče. Zbog takvog pravnog osnova i stava sekretara ili uprava tih škola, imamo tri aspekta jednog problema:

1. Svi oni koji nisu bili na prethodnom sastanku izjašnjavaju se o nečemu što čuju prvi put i nisu bili u prilici potražiti dodatne informacije vezane za tok sastanka, donesene odluke i zaključke, utvrđene rokove ili razloge za takvu podjelu poslova na izvršioce.

2. Svi oni koji su učestvovali na prethodnom sastanku i spriječeni su doći na sastanak na kojem se razmatra zapisnik, neće imati mogućnost intervencije na zapisnik. Propušta se prilika za posrednu intervenciju u pripremnoj fazi, kroz razgovor sa voditeljem sastanka ili direktnu intervenciju putem pisanog akta, koji bi bio pročitan na sastanku.

3. Najveća šteta ogleda se u tome što se odluke sa sastanaka ovog stručnog organa tiču velikog broja osoba i konkretnih izvršilaca u školi, za koje ne postoji odgovarajući kanal komunikacije. Oni se oslanjaju na posredna tumačenja i iskaze pojedinaca, umjesto na oglašene zapisnike i odluke kojim se postiže adekvatan protok informacija i veći stepen uključenosti svih.

U školama u kojima nisu oglašavani zapisnici, izvodi iz zapisnika ni odluke školskog odbora ili nastavničkog vijeća, usmenim putem se vršila razmjena informacija učesnika sastanaka sa ostalim zainteresiranim stranama. U situacijama kad je trebao neku odluku ili zaključak provesti član školskog odbora ili nastavničkog vijeća koji nije bio na sjednici, voditelj sastanka ili druga zadužena osoba prenosila mu je informacije, obaveze i rokove. Ovo govori o potrebi mijenjanja pravnog okvira kako bi se unaprijedila efikasnost u radu na 
sastancima, ali i rad u cijeloj organizaciji, pogotovo jer smo utvrdili da niko ne radi memo zapisnika, koji bi nadomjestio nedostatak izvoda iz zapisnika ili oglašene odluke. Ukoliko zapisnik sa sastanka nije samo zapis o održanom sastanku, već poželjan kanal komunikacije u poslovnoj i profesionalnoj organizaciji, ili medij za slanje poruka, počet ćemo, svi zajedno, razumijevati značaj oglašenih zapisnika i odluka kao alata za upravljanje pomoću sastanaka.

\section{Spremnost rukovodilaca na usavršavanje}

Realizirano istraživanje o sastancima pokazalo je opredijeljenost rukovodilaca javnih ustanova iz uzorka da svoju profesionalnu ulogu, u kontekstu kontinuiranog profesionalnog obrazovanja, ne prihvataju samo kao rukovođenje organizacijom koja poučava vrijednosti, već taj koncept proširuju na učenje i obrazovanje odraslih. U tom svjetlu vide i sebe, kao prvog među jednakima, kad se uključuju u razne vidove formalnog ili neformalnog obrazovanja. Pet od osam rukovodilaca škola iz uzorka pohađalo je i/ili uspješno okončalo poslijediplomske studije s ciljem kontinuiranog profesionalnog obrazovanja i razvoja kompetencija nužnih za uspješno nošenje sa reformskim procesima u obrazovanju i upravljanje promjenom. Unutar ideje o cjeloživotnom učenju gradili su učeće organizacije, otvarajući vrata spoznaje profesionalcima u školi kao takvoj. Zadati institucionalni okvir nije im u tome bio prepreka. Programi obuke kreirani za profesionalce u školama stizali su iz nevladinog sektora, iz akademske zajednice te strukovnih udruženja i stručnih tijela pri obrazovnim vlastima, a realizirali su se u školi. Načini i oblici participacije rukovodilaca na obukama određeni su ciljevima obuke i kompetencijama svakog od njih ponaosob. Škola je sve više postajala prostor otvoren za rast i razvoj pojedinca i organizacije u cjelini. Stvarajući prilike za obuke u osnovnoj školi, učenje i obrazovanje odraslih dobilo je svoj dom i u javnim školama. Menadžment model, koji svoj osnov ima u teoriji, a provediv je u praksi potvrdio je na djelu „(...) da svakoj organizaciji, pa i obrazovnoj, treba menadžment radi smislenog planiranja, organizovanja, usmjeravanja i razvoja ljudskih potencijala, vrednovanja objektivnih i subjektivnih resursa, a sve zarad efikasnijeg ostvarivanja ciljeva obrazovnog sistema i svake obrazovne organizacije/ ustanove ponaosob“ (Avdagić $2016: 13$ ). 


\section{Potreba za obukom rukovodilaca o vođenju sastanaka}

Govoreći o filozofiji doživotnog obrazovanja i učenja, Alibabić (2011: 86) u prvi plan stavlja promjenu u sistemu: „Za očekivati je da se obrazovni sistem sve više diversifikuje, da se tradicionalni školski sistem 'otvara' za potrebe odraslih, da se integrišu (pod)sistem formalnog (školskog) obrazovanja i (pod)sistem neformalnog obrazovanja“. Ranije smo naveli rezultate koji pokazuju kako zadati institucionalni okvir rukovodiocima nekih osnovnih škola u Bosni i Hercegovini nije bio prepreka da škole „otvore” za programe i obuke koje podupiru koncept obrazovanja odraslih. Rukovodilac procjenjuje kad je potrebno „iskoračiti iz zone komfora"i zauzeti novi kurs u pogledu cjeloživotnog učenja i obrazovanja odraslih u organizaciji, čime će omogućiti dalji razvoj škole kao učeće organizacije.

Ovdje je riječ o prekinutoj ravnoteži institucije, za šta je potrebno pripremiti organizaciju i njene članove. Jedan od modela obuke opisao je Lewin (prema Bovee, 1999), a on uključuje: odmrzavanje, implementaciju i stabilizaciju promjene. Posmatrano konkretno na primjeru obuke za vođenje sastanaka, važno je sačiniti cjelovit, andragoški utemeljen program obuke, koji će biti u funkciji unapređenja znanja i vještina za rad na sastancima, odnosno usvajanja novih oblika rada i obrazaca ponašanja u različitim fazama sastanka. Proučavanje literature i rad na istraživanju sastanaka, uz redovnu samorefleksiju, doveli su nas do prijedloga praktikuma koji se može izraditi za organizatore i voditelja sastanaka. On bi u sebi sadržavao niz konkretnih prijedloga i uputa, objedinjenih na jednom mjestu, koji dalje vode ka ostvarenju „tri posebno važne orijentacije u strategijskom planu obrazovanja: a) inoviranje, b) jačanje kvalitete i c) snižavanje troškova. Prva zahtijeva ljude koji rade drugačije, druga ljude koji rade bolje i spretnije, a treća ljude koji rade marljivije..." (Slatina 2012: 46). Sastanci su izvanredna prilika da se te tri orijentacije ukorijene u strateški plan razvoja škole kao organizacije. Stoga nam treba menadžment u obrazovanju koji može iznijeti odgovornost za takvu promjenu. Glavna preokupacija (polazna i završna tačka) menadžmenta u obrazovanju moraju biti svrhe, ciljevi i ishodi obrazovanja, dok su upravljačke procedure i obrasci, usmjeravanje i podsticanje zaposlenih samo mehanizmi u službi glavnih preokupacija (Avdagić 2016: 19). 
Naprijed iznesena argumentacija navodi nas na zaključak da je otvorena utakmica za širenje koncentričnih krugova spoznaja u području vođenja sastanaka. Ukoliko bi organizirali obuku za sve potencijalne kandidate za menadžerske pozicije - direktore, pomoćnike direktora, stručne saradnike, razrednike i sve voditelje timova - kao i aplikante za članstvo u upravnim i nadzornim odborima, pretpostavka je da bi sastanci u školama bili efikasniji. Za rezultat bi imali kontinuirani revolucionarni model promjene (Alibabić 2010: 108), što je trenutno, zbog obima programa i aktuelnih zakonskih rješenja u segmentu obrazovanja odraslih, prilično teško provesti u praksi. Za taj korak u radu i razvoju škole kao organizacije odluke se donose na organima upravljanja i rukovođenja. Prethodno se radi SWOT analiza potreba i stanja u organizaciji, odnosno interesa pojedinaca u njoj. Rezultati istraživanja sa direktorima škola ukazali su na niz neophodnih koraka u kreiranju programa obuke za rukovodioce ustanova kako bi mogli aktivno učestvovati u procesu transfera znanja na svoje kolege u organizaciji. Njih detaljno opisujemo u nastavku rada.

U dijelu našeg istraživanja zasnovanog na analizi pedagoške dokumentacije u školi, osnovni izvor podataka i informacija bili su zapisnici. Stoga njima pripada posebno mjesto u praktikumu koji predlažemo. U prilog tome, identificirali smo dva područja gdje je primjetna potreba za učenjem i pripremom. Naime, vođenje zapisnika zahtijeva posebne vještine sublimacije diskusije i navođenja ključnih tačaka, međutim, ne postoji formalni vid obuke za taj odgovorni posao. Ove činjenice treba imati u vidu prilikom osmišljavanja programa podrške ili obuke za osposobljavanje što većeg broja osoba za vođenje zapisnika. Ovaj vid podrške naročito je važan za profesionalne organizacije poput škola, gdje zapisnici organa upravljanja i najvišeg stručnog organa - nastavničkog vijeća, čine dio arhivske građe i trajno se čuvaju. Na temelju dobivenih istraživačkih rezultata, predlažemo da praktikum sadrži dijelove različitih uputstava za vođenje zapisnika sa sastanka, objedinjene u listu od 15 tačaka, za koje procjenjujmo da ih treba sadržavati vjerodostojan zapisnik:

1. Naziv organizacije ili organa, sa rednim brojem sastanka

2. Datum održavanja sastanka i mjesto (naznaka prostorije)

3. Vrijeme početka i završetka sastanka

4. Imena voditelja sastanka i zapisničara (uz podatke o funkciji ili radnoj poziciji) 
5. Broj prisutnih učesnika sastanka

6. Broj odsutnih članova i njihova imena (za redovne sastanke i razloge izostanka)

7. Predlaganje i utvrđivanje dnevnog reda

8. Primjedbe na zapisnik sa prethodnog sastanka i usvajanje zapisnika

9. Čitanje memo podsjetnika (odluke, zaključci, izvršioci, resursi, rokovi) $s$ prethodne sjednice $i$ analiza realizacije

10. Tok sastanka: glavni predmet diskusije po tačkama dnevnog reda, imena izvjestilaca sa funkcijama, imena učesnika u diskusiji i diskusija ukratko, izvorni zapis diskusija za učesnike koji to zatraže, nedovršena problematika, nova pitanja i ideje

11.Izjašnjavanje po tačkama dnevnog reda (prihvata se informacija, donosi se odluka, usvaja se zaključak) sa upisom podataka o načinu glasanja i broju glasova

12.Definirani zaključci i odluke po svakoj tački dnevnog reda, te utvrđena zaduženja -imena izvršilaca, sredstva za realizaciju, rokovi za memo podsjetnik i prilozi (materijali za arhivu)

13.Popis osoba i institucija kojima se dostavlja zapisnik i memo podsjetnik 14.Potpisi voditelja sastanka i zapisničara

15.Potpisi ovjerivača zapisnika (na izbornim sastancima)

Obuka osoba kojima se dodjeljuje uloga zapisničara vrlo je važno područje utjecaja za rukovodioca kad znamo da strukturiran zapisnik čini bazu odluka i zaključaka za izradu plana mjera, okosnicu zaduženja po izvršiocima, pa, u konačnici, i mehanizama kontrole. Memo zapisnika predstavlja koristan alat za komunikaciju između učesnika sastanka te svih osoba i institucija kojih se taj sastanak i njegove odluke tiču. Najveća vrijednost uvođenja memo podsjetnika je uspostava jedinstvenog pristupa oglašavanja ključnih aspekata rada na sastancima. Navedeno se može dalje razvijati u teme ili ideje za razradu u praktikumu, posebno kod izrade praktičnih zadataka u andragoškom programu obuke za rukovodioce. 


\section{Andragoški praktikum za obuku rukovodilaca za vođenje sastanaka}

Praktikum nudimo kao svojevrsni priručnik iz kojeg se izvlače teme važne za obuku i teze za predavače. Također ga mogu koristiti edukatori da crpe razne materijale i razrađene upute za davanje praktičnih zadataka učesnicima obuke, kao i ostali učesnici sastanaka da bi poboljšali nivo znanja i vještina u području osposobljenosti za efikasniji rad na sastancima. Prvi korak u organizaciji sastanka jeste definisati njegove ciljeve. To je zadati okvir u kojem će se sastanak odvijati. Riječ je o procesu koji se uči i s vremenom usavršava. Cilj/evi sastanka navode se u agendi kao dodatak dnevnom redu u cjelini ili se unose zasebno, za pojedine tačke dnevnog reda. Program obuke o metodologiji postavljanja i definisanja ciljeva unaprijedit će kompetencije rukovodilaca potrebne za aktivno učešće u svim fazama sastanka. Proučavanjem dostupne literature koja tretira tu temu (Grković 2004; Slatina 2008; Karnegi 2010), zatim bilješki sa edukacija (Šunje 2002), rezultata istraživanja na terenu i ličnih iskustava u organizaciji sastanaka, sačinili smo popis od 13 grupa ciljeva. Dodatno smo ih opisali i pojasnili u drugom dijelu tabele, radi bolje identifikacije i lakše primjene u procesu postavljanja ciljeva, kod izrade dnevnog reda ili agende sastanka. 
Tabela br. 1. Ciljevi sastanaka sa opisom i pojašnjenjima

\begin{tabular}{|c|c|c|}
\hline Red. & Ciljevi sastanka & Opis i pojašnjenje \\
\hline & Razmjena informacija & $\begin{array}{l}\text { Davanje i primanje informacija u interesu boljeg protoka informacija } \\
\text { unutar organizacije, ali bez donošenja odluke }\end{array}$ \\
\hline & $\begin{array}{l}\text { Brainstorming i } \\
\text { naš krug rješenja }\end{array}$ & $\begin{array}{l}\text { Stvaranje ideja, prijedloga ili inicijativa i druge mogućnosti za nove } \\
\text { pristupe u radu grupe ili organizacije }\end{array}$ \\
\hline & Učenje i poučavanje & $\begin{array}{l}\text { Prezentacije, predavanja, savjetovanja i drugi vidovi poučavanja i učenja } \\
\text { koji doprinose usvajanju novih tehnologija, metoda, vještina, ponašanja } \\
\text { i sl. }\end{array}$ \\
\hline & Strateško planiranje & $\begin{array}{l}\text { Rasprava o strategijama, planovima unutar grupe/organizacije, } \\
\text { programima (stanje, uvidi, selekcija, procjena alternativa) }\end{array}$ \\
\hline & Konstituisanje & $\begin{array}{l}\text { Davanje legitimiteta i stvaranje uslova za početak djelovanja nekog } \\
\text { organa }\end{array}$ \\
\hline & Izbor i imenovanja & $\begin{array}{l}\text { Postavljanje osobe na neku dužnost unutar grupe (član tima, funkcija) i } \\
\text { imenovanje predstavnika izvan grupe }\end{array}$ \\
\hline & Rješavanje problema & $\begin{array}{l}\text { Dogovori i traženje rješenja iz domena redovne problematike ili } \\
\text { vanredne situacije dvije ili više osoba }\end{array}$ \\
\hline & Utvrđivanje protokola & $\begin{array}{l}\text { Utvrđivanje popisa aktivnosti i redoslijeda istupa govornika na } \\
\text { godišnjici, komemoraciji, svečanosti i sl. }\end{array}$ \\
\hline & $\begin{array}{l}\text { Donošenje } \\
\text { odluka }\end{array}$ & $\begin{array}{l}\text { Dogovor o aktivnostima iz djelokruga rada grupe koje imaju utjecaja i } \\
\text { na osobe izvan te grupe }\end{array}$ \\
\hline & Izvještavanje & $\begin{array}{l}\text { Podnošenje periodičnih izvještaja na sastancima koji su propisani aktima } \\
\text { o organiziranju }\end{array}$ \\
\hline & $\begin{array}{l}\text { Izgradnja tima } \\
\text { (team-building) }\end{array}$ & $\begin{array}{l}\text { Podjela zaduženja, odnosno zadataka na izvršioce uz podjelu } \\
\text { odgovornosti učesnika za rezultat u radu grupe }\end{array}$ \\
\hline & Promocije & $\begin{array}{l}\text { Promotivne aktivnosti i postupci usmjereni na uvođenje novog } \\
\text { proizvoda, nove poslovne politike radi povećanja obima poslovanja, } \\
\text { kvaliteta usluga i proširenja tržišta roba i kapitala }\end{array}$ \\
\hline & Zagovaranje & $\begin{array}{l}\text { Obrazloženje novih zakonskih i drugih rješenja koja doprinose promjeni } \\
\text { postojećih odnosa i koncepata kod utjecajnih grupa ili pojedinaca }\end{array}$ \\
\hline
\end{tabular}

U praksi su se pokazale četiri bitne koristi od postavljenih ciljeva sastanka:

1. Svi učesnici sastanka znaju razlog sazivanja sastanka i mogu se adekvatno pripremiti za rad i aktivno učešće u sastanku;

2. Ciljevi sastanka služe kao orijentir voditelju i učesnicima sastanka u vezi s utvrđenim tokom sastanka - konkretniji ciljevi donose usmjereniju aktivnost i rad na sastanku; 
3. U odnosu na postavljene ciljeve kasnije mogu analizirati uspješnost sastanka;

4. Upravljanje pomoću sastanaka temelji se na analizi postavljenih i realiziranih ciljeva sastanka u smislu upravljanja vremenom, ljudskim i materijalnim resursima.

U praktikum za pripremu i organizaciju sastanaka ugrađujemo još neka poglavlja koja mogu koristiti budućim voditeljima, u različitim fazama sastanka. U prvoj, pripremnoj fazi sastanka, svaki učesnik treba naučiti izraditi agendu sastanka, zatim poziv i dnevni red. Slijedi niz konkretnih uputa iz praktikuma, koje rukovodilac uzima u obzir pri izradi agende sastanka:

1. odredite ciljeve sastanka i navedite ih u pozivu - opći i pojedinačni ciljevi;

2. razjasnite željeni rezultat za svaku temu, uz pomoć pitanja i promišljanja na pozivu;

3. osmislite proces upravljanja vremenom kroz raspored tema u prijedlogu dnevnog reda;

4. sačinite listu učesnika sastanka (dužni su prisustvovati ili mogu doprinijeti rješenju);

5. pravovremeno dostavite poziv učesnicima sastanka ili ovlaštenim predstavnicima;

6. dostavite radne materijale i zapisnik sa prethodnog sastanka, uz poziv.

Poziv na sastanak voditelj ili organizator sastanka koristi za animaciju učesnika tako što će uz određene tačke dnevnog reda ili na kraju poziva staviti pitanja ili promišljanja. Pitanja se isključivo tiču tema i problematike sastanka. Kad se voditelj sastanka odluči da na poziv ispiše pitanja koja su u funkciji uspješnog rada na sastanku, on time učesnicima otkriva svoj plan sastanka: koji su mu prioriteti, ključne teme, problemi i/ili dileme. Ova metoda rada vrlo je efikasan alat u rukama voditelja sastanka u gradnji bolje radne klime i unapređenja kohezije učesnika sastanka. Za voditelje koji žele usvojiti i/ili prakticirati ovaj metod animacije učesnika za efikasniji i kvalitetniji rad na sastanku navodimo tri kriterija:

- $\quad$ prvi i osnovni kriterij: jedno pitanje = jedna tačka dnevnog reda;

- drugi kriterij: pitanja/promišljanja su kratka, jasna i nedvosmislena; 
- treći kriterij: sadržaj pitanja/promišljanja učesnike treba poticati, a ne kritizirati!

Rukovodilac se može konsultovati i sa svojim saradnicima ili članovima tima oko pitanja ili promišljanja koja će staviti u poziv na sastanak. Pitanja ili promišljanja u pozivu imaju funkciju iniciranja i drugih zainteresiranih osoba (kritičkih prijatelja): stručnjaka, poslovnih saradnika ili članova organa upravljanja, pa i gostiju za učešće i doprinos u radu na sastanku.

Stoga praktikum treba sadržavati upute za strukturiranje dnevnog reda:

- Poziv na sastanak obavezno sadrži predloženi dnevni red;

- Dnevni red se strukturira timski, kako bi se osiguralo da se uvrste sve bitne teme;

- U dnevni red se uvrste sve do tada poznate ili planirane teme za rad na sastanku, da bi se učesnici sastanka pripremili za sastanak;

- Na dnevnom redu su, kao obavezne tačke, razmatranje i usvajanje zapisnika i analiza realizacije odluka i zaključaka sa prethodnog sastanka;

- Planirani vremenski okvir se odredi u samom pozivu, okvirno za cijeli sastanak ili za svaku tačku dnevnog reda pojedinačno, tj. najavi se ograničenje vremena trajanja ili razmatranja;

- Teme koje traže više vremena za obradu i raspravu postavljaju se u vrh dnevnog reda;

- Teme za koje organizator poziva ili najavljuje goste idu također u vrh dnevnog reda;

- Dnevni red se dostavlja u pisanoj ili elektronskoj formi svim učesnicima sastanka ili se oglasi na mjestu određenom za tu namjenu;

- Kraći dnevni red, po pravilu, motivira učesnike za dolazak na sastanak, jer očekuju efikasniji rad i veći učinak sastanka;

- Kod izrade dnevnog reda nužno je voditi računa o nadležnostima koje određeno radno tijelo ili organ odlučivanja ima u svom djelokrugu rada, jer to utječe na obim i strukturu dnevnog reda. 
Stigli smo do druge faze - rad na sastanku - iz koje smo za naš praktikum izdvojili pet jasnih uputa vezanih za značaj uspostave pravila rada na sastanku:

1. Odvojite vrijeme za donošenje i uspostavu pravila rada na sastancima, ukoliko ne postoji poslovnik o radu određenog tima ili radnog tijela (organa);

2. Svakom članu grupe dostavite ili na drugi način učinite dostupnim pravila rada;

3. Rukovodilac se lično mora potruditi da se sva prava i obaveze iz pravila poštuju u cijelosti;

4. Naglasite odrednice iz pravila rada na kojima se insistira (vrijeme dostave poziva, način pravdanja izostanaka i najave kašnjenja, dužina diskusije po pojedinim pitanjima);

5. Svaki pozvani član, bio on učesnik sastanka ili ne, dužan je informisati se o odlukama i dogovorima sa sastanka kroz uvid u sadržaj zapisnika ili strukturu zaduženja unesenih u memo podsjetnik sa sastanka.

Pravila čine sistem racionalnim, prate ga u njegovoj organizacijskoj i funkcionalnoj liniji te doprinose otvaranju škole prema okruženju, na dva nivoa relacijskom i komunikacijskom. To smo iskusili istražujući na terenu i naročito u procesu obrade rezultata istraživanja. Uočili smo da zadata lista učesnika sastanka za voditelja može biti izazov, prednost ili ograničenje - sve to istovremeno u jednoj organizaciji. Kod prepoznavanja interpersonalnih odnosa u grupi učesnika sastanka vrijedi pravilo proporcije: nivo osposobljenosti učesnika za rad na sastanku srazmjeran je njihovoj samostalnosti u raspravi i procesu donošenja odluka. Da bi se postigla veća motiviranost učesnika sastanka za aktivnu participaciju u raznim fazama sastanka, voditelj im daje priliku da se osjete važnim ili da učešćem na sastanku može biti zadovoljena neka od njihovih bazičnih potreba (v. Glasser 1994). U tom okviru može se tražiti odgovor na pitanje zašto neki učesnici sastanaka samo formalno prisustvuju i vrlo malo učestvuju u radu ili se odluče da ne dođu na sastanak pravdajući to različitim izgovorima. Na voditelju je da nađe način za njihovo uključenje. Na ovom nivou, za voditelja sastanka bitno je poznavati grupnu dinamiku, jer ne smije zanemariti ulogu koju imaju „empatička tačnost“ i „kolektivna zaraza“ (v. Goleman 2008). Kroz lični angažman i preuzete uloge, učesnici se potiču na konstruktivan rad u svim fazama sastanka. 


\section{Model VIARO}

Lične potrebe i interesi pokreću ljude da budu dijelom promjene. Učešće u programima obuke za rukovodioce u konceptu strategijskog menadžmenta odgovor je na njegove potrebe i interes za cjeloživotnim učenjem. Iz perspektive zaposlenih u školama, to je posredno ulaganje i u njihov razvoj. Rukovodilac je, kao voditelj sastanaka i u individualnim razgovorima, u prilici prenijeti naučena znanja i vještine. Model VIARO proistekao je iz istraživačkih rezultata i praktičnog iskustva i namijenjen je rukovodiocima koji žele izgraditi vlastiti model strategijskog menadžmenta temeljen na upravljanju pomoću sastanaka, nakon obuke koja će ih osposobiti da stečena znanja i kompetencije primijene u ulozi voditelja sastanaka u organizaciji kojom rukovode.

Program obuke zasnovan na konceptu VIARO po svojoj dinamičkoj strukturi je ogledni model. Obuhvata pet temeljnih elemenata:

Vrijeme - posvetiti dovoljno vremena za utvrdivanje ciljeva sastanka;

Iskustva - koristiti iskustva i saznanja sa ranijih sastanaka - kako svoja, tako i tuda; Analiza - poslije svakog sastanka radi se analiza postavljenih ciljeva i utvrduje da li su realno i ispravno postavljeni;

$\boldsymbol{R} a z l o z i$ - kad se ciljevi sastanka ne ostvare, utvrditi razloge za to i predložiti mjere unapredenja;

Obuke - koristiti sve oblike rada i učenja koji mogu unaprijediti postavljanje ciljeva.

Ciklični karakter ovog modela ima pokretačku snagu za rukovodioca koji je spreman upustiti se u promjenu. Zadati okvir strategijskog menadžmenta prepoznaje svoje ogledalo u konceptu VIARO. U njemu se bazično vidi timski pristup i participativni menadžment, zatim se zrcali slojevitost relacija i kvalitet komunikacijskih obrazaca, oslikava se način donošenja odluka i zaključaka u procesima rasta i razvoja pojedinca i organizacije u cjelini, nazire se mogućnost promjene u pogledu mehanizama kontrole (od izvanjske kontrole do samokontrole) te jasno prepoznaju vizija i misija organizacije koja uči. 


\section{Vođenje sastanaka kao upravljački „alat“ u odnosu na tipove učesnika}

Sastanci su, u pravnim aktima škole, pozicionirani kao element njene organizacijske strukture. Uvidom u pravila škole i pravilnike koji reguliraju rad organa upravljanja i stručnih organa škole, ustanovili smo da se njihovi sastanci organiziraju i realiziraju u formi sjednica. Istražujući literaturu i zakonski okvir, uočili smo da sastanci školskog odbora i nastavničkog vijeća u školama imaju karakter redovnih sastanaka. Uglavnom se održavaju prema unaprijed definiranoj dinamici, tokom školske i kalendarske godine. Također, oni imaju jasno definirane ciljeve za jednu ili više tačaka dnevnog reda, što ih, u konačnici, dodatno određuje kao izborne, izvještajne, informativne, promotivne itd.

Praktikum koji predlažemo sadrži poglavlje o načinu rada sa ljudima koji su potencijalni ili već poznati učesnici sastanka. Najveći izazov i potencijalni problem voditelju sastanka predstavljaju učesnici čije se ponašanje procjenjuje kao ometajuće i štetno po uspjeh sastanka. Rukovodilac će kroz ciljanu obuku, kontinuirano vođen primjerima iz praktikuma, biti osposobljen da prepozna različite tipove učesnika i u odnosu na njihova znanja i umijeća o načinu učešća na sastancima pomoći im da prevladaju prepreke i teškoće sa kojima se u vezi s tim susreću. Status pasivnog i formalno uključenog učesnika prevazilaze samo ako dobiju jasne i konkretne inpute kako da steknu znanje ili razviju vještine koje im nedostaju. Opisani put razvoja i osnaživanje učesnika sastanka za aktivnu participaciju uopće nije lahko preći, ni učesnicima ni rukovodiocu u ulozi voditelja sastanaka. Odlučili smo da praktikum dopunimo kratkim opisom 11 tipova učesnika sastanaka (v. Grković 2002) i prijedlogom mjera i rješenja za bolju uključenost i njihov veći doprinos. Preporuke nastale kao rezultat proučavanja literature i istraživanja potvrdile su se u praksi kao uspješan model participativnog menadžmenta. Definirali smo neke zajedničke karakteristike unutar tipskog modela dok se eventualne razlike mogu pripisati različitom pristupu u istraživanju i imenovanju. Na popisu su: racionalno aktivan učesnik, djelimično aktivan učesnik, hiperaktivni učesnik, obećavajući konstruktor, neaktivan učesnik, spavač, pričljivac, gnjavator, ometalo, negator i očekivajući destruktor. 
Racionalno aktivne učesnike prepoznajemo kao osobe koje promišljeno i analitički učestvuju u svim fazama sastanka: pripremi, toku sastanka i aktivnostima poslije sastanka. U pripremnoj fazi predano rade na izvršenju preuzetih obaveza, analiziraju dostavljeni dnevni red i predlažu izmjene ili dopune, temeljito se pripremaju za odabrane teme i raspravu o njima. Poštuju vrijeme i ne kasne na sastanke, te se pridržavaju postavljenih pravila rada. Ličnim angažmanom doprinose tako što nude prijedloge odluka i rješenja koja su u interesu općeg dobra. Nakon sastanka usmjereni su na izvršenje usvojenih odluka i pripremu radnih materijala za naredni sastanak - ukoliko im je povjerena uloga uvodničara ili izvjestioca. Tumači su pozitivne strane donesenih odluka i predlažu rješenja za unapređenje rada na sastancima. Racionalno aktivni učesnici, zbog svega navedenog, vrlo su poželjni za svaku grupu. Pouzdan su oslonac voditelju. Pokretači su razvoja grupe jer konstruktivno doprinose uspjehu sastanka. Iz ove grupe učesnika regrutuju se budući uspješni voditelji.

Djelimično aktivan učesnik povremeno je aktivan na sastanku i to dobro obavi. Tok sastanka ne ometa i ne ispoljava negativna ponašanja. Svoje učešće ograničava na teme koje je pripremio i ne oduzima vrijeme. Daje zadovoljavajući doprinos, bez kontinuiranog učešća u različitim fazama sastanka.

Mjere i rješenja: djelimično aktivne učesnike rukovodilac pridobije tako što ih stalno podstiče, individualno im pristupa i ističe njihov dosadašnji doprinos. U pripremnoj fazi sastanka, rukovodilac ih direktno uključuje - pita za mišljenje o nekoj temi ili problemu, traži procjenu i potiče ih da iskažu prijedloge ili ideje u ulozi izvjestioca, analitičara teme ili predlagača odluke. Naredni korak bio bi uključivanje na obuku radi daljeg razvoja.

Hiperaktivni učesnik je osoba koja redovno učestvuje u raspravama o svim temama i u svakoj prilici. Nikada ne propušta priliku da govori. Mora se javiti za riječ! Nepotrebno troši vrijeme na sastanku jer ponavlja iskaze drugih učesnika ili ih analizira. Ne doprinosi raspravi ni radu na sastanku, s obzirom da nije konkretno uključen u pripremu sastanka.

Mjere i rješenja: rukovodilac će nakon obuke znati kako tražeći konkretne prijedloge usmjeriti istupe hiperaktivnog učesnika i upozoriti ga ako ponavlja diskusije na sastanku. Da bi riješio probleme na komunikacijskom i na odnosnom nivou, voditelj mora reagirati hitno, u skladu sa pravilima rada na sastanku. Pozivanje na pravilo o ograničenom vremenskom trajanju diskusije 
i insistiranje na konkretnom prijedlogu ili rješenju pomaže voditelju sastanka da usmjeri nametljivog učesnika. Kad je član stalnog radog tijela, treba mu dati konkretne zadatke i zaduženja u pripremi sastanka, proistekle iz rada na sastanku. Za pozitivan pristup i konkretan doprinos radu na sastanku, u bilo kojoj fazi, dati mu otvorenu podršku i pohvalu.

Pričljivac je osoba koja učestalo priča tokom sastanka ili glasno komentira i ometa rad. Pokazuje nemir i svojim aktivnostima odvlači pažnju ostalih učesnika, odnosno grupe u cjelini. Nije fokusiran na rad, što se odražava na tok i radnu klimu na sastanku.

Mjere i rješenja: „pričljivac” se konstantno mora podsjećati na pravila rada. Osim toga, rukovodilac ga upozorava da svojim ponašanjem otežava rad drugih učesnika sastanka. Potom slijedi vrlo nepopularna, ali nužna mjera: otvoren i ozbiljan razgovor rukovodioca sa pričljivcem i utvrđivanje mjere za prevladavanje takvog ponašanja. Ako dogovor ne urodi plodom, nužna je najava povlačenja/isključenja iz rada grupe, dok pričljivac ne shvati ozbiljnost situacije. $\mathrm{U}$ mandatnim timovima obično se radi zamjena učesnika.

Obećavajući konstruktor je osoba koja preuzme i obaveže se izvršiti neki posao, ali ga često ne obavi ili ga obavi samo djelimično i/ili sa kašnjenjem. Kada u timu za pripremu sastanka imate obećavajućeg konstruktora, velike su šanse da sastanak započne loše, jer pripreme nisu obavljene pravovremeno i kvalitetno - iz objektivnih ili subjektivnih razloga. Takvo ponašanje utječe na ostale učesnike, na rezultate rada i, na kraju, na ukupan (ne)uspjeh sastanka.

Mjere i rješenja: obećavajućem konstruktoru rukovodilac će prvo prestati davati važne zadatke. Druga mjera: dati mu manje zadatke uz ispomoć nekog od revnosnih učesnika. Treća i najnepopularnija mjera bila bi discipliniranje uz pomoć sankcija, ako po pravilima rada postoji takav model. Kad mu rukovodilac mora povjeriti neku obavezu, dodijelit će mu neki oblik koji omogućava vanjsku kontrolu kako bi mogao periodično provjeravati kvalitet i dinamiku izvršenja povjerenih obaveza, naročito kad se radi o članu radne ili profesionalne organizacije. U radnoj grupi ili timu mandatnog karaktera, traži se alternativa drugi izvršilac.

Neaktivni učesnici samo su glasačka mašina. Redovno dolaze na sastanke, ali su neaktivni u svim fazama sastanka. Ne traže informacije, ne iznose stavove ili mišljenja, a vrlo rijetko ili nikako ne učestvuju u raspravi i drugim aktivnostima 
na sastancima i to im nije problem. Neaktivni učesnik može predstavljati problem za rukovodioca i kolektiv usmjeren na rezultat. Neko drugi mora raditi za tu osobu. Voditelj je odgovoran za neaktivnost učesnika.

Mjere $i$ rješenja: neaktivni učesnici su izazov za rukovodioce. Zato što je neprihvatljivo zauzeti stav da je on ,jednostavno takav”, da to nije briga rukovodioca već samog učesnika i da se voditelj nema vremena baviti njime, plediramo da se praktično razrade koraci podrške ovom tipu učesnika na obuci za rukovodioce. Važno je jer grupa/ustanova ili organizacija ne funkcionira dobro ako se ne vodi briga o svakom članu. Na rukovodiocu je da napravi plan aktivnosti i riješi problem. Nužno je sagledati razloge zbog kojih neki učesnici imaju takav odnos. U lepezi razloga može biti da učesnik nema interes za temu, da nije pripremljen ili upućen u problematiku ili se ne smatra dovoljno stručnim za raspravu o nekoj temi, ima tremu ili strah od javnog nastupa, komplekse. Pomoć u radu sa neaktivnim članovima rukovodiocu mogu pružiti aktivni učesnici. Uspjeh je to cijele grupe ako se aktivira dotad neaktivan učesnik. Pomoć, pohvale i podrška dio su procesa uspješnog vođenja ovog tipa učesnika sastanka. Nakon što procijeni osobu i dobije lični pristanak, slijedi uključenje u neke od oblika aktivnosti na sastanku - izvještaj o radu sekcije ili ispitne komisije. Ako postoji program obuke za učešće na sastanku, uključiti ga uz redovan nadzor i doziranu podršku.

Spavač je učesnik koji ne prati tok sastanka. Dosadno mu je i radi nešto za sebe. Ne primjećuje događanja na sastanku i ništa ga ne zanima. Neaktivan je u raspravama. Spavalačkim izgledom dekoncentrira ostale učesnike, što se negativno odražava na radnu klimu sastanka.

Mjere i rješenja: rukovodilac će „spavača” uključiti pozivom da prati, upozoriti ga na potrebu promjene ponašanja, ili će ga jednostavno pitati za mišljenje kako bi se "probudio” i aktivirao. Naredni korak bio bi individualni razgovor voditelja sa „spavačem” ukoliko je član stalnog tijela. Ključ rješenja za ovaj tip učesnika leži u činjenici da nerado govore o svojim potrebama i interesima. Očekivana promjena ponašanja dogodit će se kad rukovodilac ustanovi koje su njegove osnovne potrebe koje prisustvom na sastanku nastoji zadovoljiti.

Gnjavator je učesnik sastanka koji se često javlja za riječ, mnogo govori, okoliša, skreće $s$ teme i razvlači raspravu. Troši mnogo vremena na smušena izlaganja, bez jasnog iskaza ili misaone niti u odnosu na temu rasprave. Ne daje 
konkretan doprinos sastanku. Tumači iskaze, ponavlja prethodne govornike i mišljenja autoriteta iz grupe ili izvan nje.

Mjere i rješenja: intervencije rukovodioca će biti uspješne kad uspije sagledati razloge zašto se ponašanje gnjavatora na sastancima ponavlja. Dužan je ukazati mu na često skretanje $s$ teme i tražiti da bude određeniji i što jasniji u iznošenju stavova, kroz parafraziranje ili sažimanje dotad izgovorenog u diskusiji. Najbolje rješenje: donijeti zaključak o ograničenom trajanju diskusija. Kad ta mjera nije dogovorno postignuta, voditelj usmjerava tok diskusije postavljanjem konkretnih pitanja vezanih za temu i istrajavanjem na dosljednoj primjeni usvojenih pravila rada na sastanku. Drugi konkretan vid pomoći ogleda se u isticanju jasnog pitanja, prijedloga ili rješenja na koje odgovor učesnika iz te grupe mora biti potvrdan. I ovoj grupi učesnika dobro bi došla planski vođena obuka za unapređenje znanja i vještina za učešće na sastancima, uz obavezan vid kontrole ili podrške.

Ometalo je učesnik sastanka koji ima naviku da učestalo prekida druge učesnike u njihovim aktivnostima. To je naročito izraženo kada ostali učesnici raspravljaju o njegovom učešću - iznesenoj informaciji, izvještaju, prijedlogu jer ne poštuje pravila rada niti autoritet voditelja. Svojim ponašanjem pretvara sastanak u polemiku, što je samo korak do nesuglasica i sukoba.

Mjere i rješenja: rukovodilac nikako ne želi polemiku među učesnicima sastanka pa će intervenirati. Prva opcija: razgovor o nužnosti poštovanja pravila rada i vremena učesnika sastanka. Ako ometalo nastavi sa svojim ponašanjem, rukovodilac primjenjuje pravilo o oduzimanju riječi ili isključenju iz rada na sastanku. Ako se ometač ni tad ne zaustavi, pred grupu se stavlja izazov da rasprave o ometajućem ponašanju tog učesnika - svi učestvuju jer ih sve ometa. Cilj je imati učesnika koji osjeća afirmativnu pripadnost grupi, jer se ponaša u skladu sa zahtjevima grupe i poštuje njihovo vrijeme.

Negator je učesnik sastanka koji učestalo negira aktivnosti, stavove, promišljanja i prijedloge grupe ili pojedinaca. Omalovažava predlagače i izvjestioce, te druge učesnike koji nastoje dati pozitivan doprinos u aktivnostima vezanim za sastanak. Tvrdi da stvari nisu dobre, ali za to nema argument. $\mathrm{Na}$ iznesene primjedbe ne nudi rješenja. On smatra da je iskazom o tome da nešto ne valja svoj posao završio. Njegovo djelovanje je negatorsko u svim fazama sastanka. Negator djeluje otvoreno na sastancima, ali i prikriveno (u kuloarima), što konstantno opterećuje rad i funkcioniranje grupe. 
Mjere i rješenja: rukovodilac će javno ukazati „negatoru” da se od njega očekuje konkretan prijedlog ili rješenje problema o kojem diskutuje, umjesto negacije rješenja i prijedloga koje su iznijeli drugi učesnici. Davanje konkretnih individualnih zadataka drugi je korak - „zagušenje” radom. Grupa po pravilu nije naklonjena negatoru i teško je sarađivati s njim, što nameće potrebu za hitnom promjenom. U mandatnim timovima rješenje je zamjena novim članom. Ali, kad takvu osobu imate u organizaciji, ostaje vam da je privolite ili primorate da se uključi u obuku za unapređenje znanja/vještina za rad na sastancima - ako ta vrsta obuke postoji.

Očekivajući destruktor je učesnik koji svojim ponašanjem izaziva neslaganja i sukobe među učesnicima sastanka. Rijetke su radne sredine u kojima ne postoji neki očekivajući destruktor. Svojim djelovanjem ovaj tip učesnika uzrokuje da sastanak bude neuspješan. Sklonost destruktivnom ponašanju manifestuje se kroz svađalački ton u obraćanju ostalim učesnicima sastanka, učestalo agresivno upadanje u riječ, nekvalitetno i zakašnjelo izvršavanje preuzetih obaveza od značaja za grupu itd.

Mjere i rješenja: rukovodilac ima vrlo težak zadatak, da očuva homogenost grupe a da ne ukloni destruktora iz grupe. Stoga je bitno imati akte kojima su jasno definirane procedure za upravljanje tokom sastanka. Za rukovodioca je to sredstvo utjecaja od posebne važnosti kod periodičnih sastanaka radnih grupa i stručnih organa. Kad se spoznaju razlozi i motivi tog izazovnog ponašanja, energija rukovodioca se usmjeri ka nekom od obrazaca i rješenja koja su zajednička za sve tipove učesnika koji ispoljavaju ometajuće ponašanje. Cilj je porušiti barijere nastale kao rezultat stege i prisile, a uvesti saradnički pristup zasnovan na principima teorije izbora (Glasser 1994).

Koordinacija aktivnosti i koraka koje poduzimaju rukovodioci u ulozi voditelja sastanka u saradnji sa drugim učesnicima oslikava njihove odnose. Potcrtavamo stav koji se tiče kvaliteta komunikacije u organizaciji. „Dobro razumijevanje utjecanja važno je za menadžerski rad na svim razinama. Menadžer mora biti čovjek koji djeluje potičući i unapređujući ponašanje i aktivnosti ljudi. [...] Snaga utjecanja na druge je socijalizirana i usklađena s kolektivnim ciljem“ (Slatina 2008: 3). Ne mijenjaju se stvari u organizaciji same po sebi, već tu promjenu čine ljudi koji svojim učešćem i radom na sjednicama doprinose da sastanci postanu dijelom mehanizma upravljanja u organizaciji. Svaki učesnik 
sastanka u tome ima svoj dio odgovornosti, ali se ipak najviše očekivanja stavlja pred rukovodioce. „Vrijeme koje ulažemo u dobro vođene sjednice tima, dugoročno će se višestruko isplatiti, budući da se tu može stvoriti osnovica za rad koji će odolijevati i teškim situacijama. Metakomunikacija u timu znači, uvijek iznova - na redovitim, barem mjesečnim sjednicama - zastati u radnoj svakodnevnici, kako bismo povukli privremenu bilancu: 'Jesmo li još na pravom putu načinom kako postupamo i međusobno se ophodimo? Ili su potrebne promjene kursa?' To nazivamo metakomunikacijom, stoga, što se postavljamo iznad svakodnevnog zbivanja, svakodnevne komunikacije i radnu svakodnevnicu promatramo odozgo, s određene udaljenosti“ (Schulz von Thun 2001: 103). Utvrdili smo da ne postoji ni jedan potpuno „čist“ i jasno prepoznatljiv stil upravljanja koji voditelj sastanka preferira u svom radu na sastancima i u školi uopće.

\section{Zaključak}

Vremena krize su bremenita izazovima, ali i novim prilikama za razvoj. Za nosioce ideje o promjeni u strategijskom menadžmentu nominirani su rukovodioci organizacija kroz objedinjene menadžerske, liderske i andragoške kompetencije. Rukovodiocima koji zakorače na put razvoja ličnih i profesionalnih kompetencija potrebna su sredstva (programi obuke), modeli (VIARO) i alati (Praktikum) da bi ostvarili promjenu u organizaciji kojom rukovode. „Na toj se osnovi otvara prostor za razumijevanje kako temelj profesionalne pripreme andragogiju tvori ne samo 'mreža' praktičnih znanja, već, u znatnijoj mjeri, stalno promjenjiva, razvojna teorija, koja ima kapacitete da potakne i proizvede pozitivnu interakciju između andragoga i odraslih učenika u zajedničkom procesu učenja“ (Ovesni i Alibabić 2012: 9). Model VIARO je naš prijedlog rješenja za rukovodioce koji žele izgraditi vlastiti model strategijskog menadžmenta temeljen na upravljanju pomoću sastanaka, nakon obuke koja će ih osposobiti da stečena znanja i kompetencije primijene u ulozi voditelja sastanaka u organizaciji kojom rukovode. Kroz program obuke zasnovan na modelu VIARO, rukovodiocu se nudi set alata koji su u funkciji razvoja njegovih znanja i vještina za bolje upravljanje vremenom i ljudskim resursima u svim fazama sastanka - od faze pripreme do provedbe odluka donesenih na sastanku. Kad se jedanput pokrene ciklus pripreme i organizacije sastanaka po modelu VIARO, za rukovodioca će to 
biti iskorak u područje strategijskog menadžmenta, čiju bazu čini timski pristup i participativni menadžment. Po principu „korak po korak“ rukovodilac pokreće intrinzičnu motivaciju učesnika sastanka, što ih usmjerava ka grupi učesnika osposobljenih da nose odgovornost uvodničara, konstruktivnih diskutanata ili kompetentnih analitičara.

Ako se ne može utjecati na pozitivnu selekciju osoba za poziciju rukovodioca, onda se može kreirati program obuke koji pomaže da iskorače iz faze „uči upravljanje upravljajući“, u fazu strategijskog pristupa menadžmentu u obrazovanju. Učiti, raditi samoevaluacije i refleksije na učinjeno, propitivati teoriju u praksi i obrnuto - put je koji vodi ka uspjehu u upravljanju sastancima, kao i upravljanju organizacijom. Stečena znanja i vještine upravljanja sastancima, tokom i nakon obuke, rukovodioci primjenjuju u organizaciji, po modelu koji zagovara Savićević (2010) kad govori o psihologiji učenja odraslih kroz pet područja. Evaluacija programa obuke i licenciranje učesnika obuke naredni su zadaci na tom putu. 


\title{
Andragogic Practicum for Educational Management - VIARO Model in Managers Training Program
}

\begin{abstract}
The need for a comprehensive training program for managers in schools as business organizations is argued in this paper, along with recommendations for its implementation. It is proposed that meeting training be included as part of this program, from planning and conducting meetings to decision-making and implementation. The program's recommendations were based on findings from interviews with school principals, documentation analysis, and the author's own self-reflection on her managerial work. Time, experiences, analyses, reasons and trainings are the four parts that make up the VIARO model as a means and tool for enhancing the capabilities of all school staff in the position of meeting participants. The paper describes its role, goals and significance from the standpoint of adult learning and education outcomes.
\end{abstract}

Keywords: educational management, administration, meetings, training program, practicum, VIARO model. 


\section{Literatura}

Alibabić, Š. 2010. Obrazovanje i učenje odraslih - Jezgro menadžmenta promene. Obrazovanje odraslih. br. 1, 103-118.

Alibabić, Š. 2011. Konceptualne i organizacione karakteristike daljeg obrazovanja. Obrazovanje odraslih. br. 2, 83-95.

Avdagić E. 2016. Menadžment modeli u organizacijama za obrazovanje odraslih [online]. Sarajevo: Institut za međunarodnu saradnju Njemačkog saveza visokih narodnih škola - DVV International (Ured u Bosni i Hercegovini). Dostupno na: http:// www.dvv-internacional.ba/bs/materijali/publikacije/ [15.8.2021.].

Glasser, W. 1994. Kvalitetna škola. Zagreb: Educa.

Goleman, D. 2007. Socijalna inteligencija: Nova nauka o ljudskim odnosima. Beograd: Geopoetika.

Grković, M. 2002. Sastanci-Upravljanje vremenom: Kako uštedjeti vrijeme na sastancima, a postizati vrhunske rezultate? Belišće: Vlastita naklada.

Grković, M. 2004. Model UPS: Upravljanje pomoću sastanaka. Belišće: Centar za unapređenje sastanaka.

Isanović, A. 2011. Andragoška realnost menadžmenta u obrazovanju. Obrazovanje odraslih. br. 1, 23-46.

Jasika, A. 2017. Sastanci kao oblik kolektivnog rada i odlučivanja u osnovnoj školi. Neobjavljeni magistarski rad. Sarajevo: Filozofski fakultet Univerziteta u Sarajevu.

Karnegi, D. 2010. Psihologija uspeha za 21. vek - Komunikacijom do uspeha. Beograd: Amiral Books.

Ljujić, B. 2011. Menadžerske kompetencije instruktora u online obrazovanju odraslih. Obrazovanje odraslih. br. 1, 47-62.

Ovesni, K., Alibabić, Š. 2012. Obrazovanje odraslih: ključni čimbenici i novi izazovi u procesu profesionalizacije. Andragoški glasnik. vol. 16, br. 1, 7-20.

Savićević, M. D. 2010. Istraživačka teritorija andragogije. Obrazovanje odraslih. br. 1, 87-102.

Slatina, M. 2008. Organiziranje kao menadžment funkcija i vještina. Didaktički putokazi. br. 48, 2-9.

Slatina, M. 2009. Odlučivanje kao menadžment funkcija i vještina. Didaktički putokazi. br. $50,28-38$

Slatina, M. 2013. Kontrolna funkcija menadžmenta u obrazovanju: Od kontrole do samokontrole. Sarajevski žurnal za društvena pitanja. Vol. 2. Broj 1, 57-76.

Staničić, S. 2008. Suvremeni trendovi u školskom menadžmentu, Dostupno na: www.azoo. $\mathrm{hr} /$.../Suvremeni_trendovi_doc. [11.8.2016.].

Schulz von Thun, F. 2001. Kako međusobno razgovaramo - Psihologija komunikacije za rukovoditelje. Zagreb: Erudita.

Šunje, A. 2002. Menadžment u obrazovnim ustanovama. Bjelašnica, Predavanje na seminaru: Menadžment u obrazovanju, 2-4. oktobar 2002. 